\title{
Prognostic factors in the acute respiratory distress syndrome
}

Wei Chen ${ }^{1,2,3,4^{*}}$ and Lorraine B Ware ${ }^{1,5}$

\begin{abstract}
Despite improvements in critical care, acute respiratory distress syndrome (ARDS) remains a devastating clinical problem with high rates of morbidity and mortality. A better understanding of the prognostic factors associated with ARDS is crucial for facilitating risk stratification and developing new therapeutic interventions that aim to improve clinical outcomes. In this article, we present an up-to-date summary of factors that predict mortality in ARDS in four categories: (1) clinical characteristics; (2) physiological parameters and oxygenation; (3) genetic polymorphisms and biomarkers; and (4) scoring systems. In addition, we discuss how a better understanding of clinical and basic pathogenic mechanisms can help to inform prognostication, decision-making, risk stratification, treatment selection, and improve study design for clinical trials.
\end{abstract}

Keywords: Acute respiratory distress syndrome; Prognostic factors; Biomarkers; Oxygenation; Scoring system

\section{Introduction}

The acute respiratory distress syndrome (ARDS) is a devastating syndrome of pulmonary inflammation and edema manifested clinically by the acute onset of bilateral infiltrates on chest radiograph, and arterial hypoxemia [1-3]. Despite advances in the care of critically ill patients, both short and long-term mortality rates of ARDS remain high [4]. Currently, the only therapy that has been definitively proven to reduce mortality in ARDS is a lower tidal volume ventilator strategy [5]. However, other therapies have been shown to reduce mortality in a subset of patients with ARDS. For example, application of prone positioning in patients with severe ARDS (defined for this study as a ratio of the partial pressure of arterial oxygen to the fraction of inspired oxygen $[\mathrm{PaO} 2 / \mathrm{FiO} 2]$ of less than $150 \mathrm{~mm} \mathrm{Hg}$ ) significantly decreased 28-day and 90-day mortality [6]. Thus, a better understanding of prognostic factors in ARDS is crucial for facilitating risk stratification and developing new therapeutic interventions that aim to improve clinical outcomes. The aim of this article is to review known clinical predictors and biologic markers of mortality in

\footnotetext{
* Correspondence: peteralfa2004@yahoo.com.tw

${ }^{1}$ Division of Allergy, Pulmonary, and Critical Care Medicine, Department of Medicine, Vanderbilt University School of Medicine, Nashville, USA ${ }^{2}$ Division of Pulmonary and Critical Care Medicine, Chiayi Christian Hospital, 600 Chia-Yi, Taiwan

Full list of author information is available at the end of the article
}

ARDS. We categorize the prognostic factors into four areas including (1) clinical characteristics; (2) physiological parameters and oxygenation; (3) genetic polymorphisms and biomarkers; and (4) scoring systems. In addition, we discuss how a better understanding of clinical and basic pathogenic mechanisms can help to inform prognostication, decision-making, risk stratification, treatment selection, and improve study design for clinical trials.

\section{Review \\ Clinical characteristics}

There have been a number of large studies over the past several decades that have explored clinical risk factors for hospital and short-term mortality in ARDS. Clinical predictors that were consistent across multiple studies include older age, worse physiologic severity of illness (as measured by severity scores such as the Acute Physiology and Chronic Health Evaluation (APACHE) or Simplified Acute Physiology Score (SAPS)), shock on hospital admission, arterial $\mathrm{pH}$ less than 7.30, liver disease, early air leak, immunosuppression, triggering risk factor, and right ventricular dysfunction [7-11]. It is important to note that these studies were all done before the era of lower tidal volume ventilation. In more recent studies done in clinical trial patient populations after the widespread implementation of low tidal volume

\section{实}


ventilation, severity of illness as measured by APACHE II or APACHE III has remained a robust clinical predictor of mortality as have age, and the presence of nonpulmonary organ failures $[12,13]$.

In regards to effects of race and ethnicity on mortality from ARDS, a retrospective cohort study from the $\mathrm{Na}$ tional Institutes of Health (NIH) ARDS Network revealed that African American and Hispanic patients have a higher mortality from ARDS than Caucasian patients [14]. The mechanisms that underlie this racial disparity in mortality are unknown; one proposed factor is related to the high incidence of a mutation in the promoter region of the Duffy antigen/receptor for chemokines (Darc) gene in those of African ancestry that leads to low levels of erythrocyte Duffy antigen, reduced chemokine binding and potentially to higher levels of circulating chemokines such as IL-8 [15]. In a large multicenter study, Lemos-Filho LB et al. found that AfricanAmerican patients were less likely to develop ARDS than Caucasians even after adjustment for clinical predictors despite having higher severity of illness at presentation. In the same study, there was no difference in ARDS mortality by sex or race after adjustment for covariates [16]. Recently, Reilly et al. reported that blood type A is a risk factor for ARDS in Caucasian patients with major trauma and sepsis [17]. However, it is not known whether the same blood type is also associated with poor prognosis in ARDS and this study has yet to be validated in another patient population.

The role of diabetes in the development of ARDS is still controversial. Koh et al. showed that diabetes mellitus is not associated with development of ARDS in a large cohort of critically ill patients [18], although patients with diabetes had higher mortality regardless of ARDS status. By contrast $\mathrm{Yu}$ et al. reported a protective effect of diabetes on development of ARDS [19], but diabetes had no association with outcomes.

Most of the original studies of clinical risk factors for mortality in ARDS have focused on short-term outcomes such as hospital or 28-day mortality. However, it is increasingly clear that long-term mortality after ARDS and other critical illness is substantially higher than shortterm mortality; long-term mortality may be driven by different factors than short-term. A multi-intensive care unit, prospective cohort study of 646 patients hospitalized with ARDS showed that mortality at 1 year was substantially higher than in-hospital mortality $(41 \%$ vs. $24 \%, p<0.001)$. The independent predictors of death at 1 year were age, living somewhere other than home prior to admission, and serious comorbidities such as HIV and malignancy [20]. For very severe ARDS patients requiring extracorporeal membrane oxygenation (ECMO) intervention, Schmidt et al. constructed a mortality prediction model with eight pre-ECMO parameters, i.e., age, body mass index, immunocompromised status, prone positioning, days of mechanical ventilation, sepsis-related organ failure assessment, plateau pressure and positive end-expiratory pressure; this scoring system accurately predicted long term mortality in this select group of severely ill ARDS patients [21].

\section{Physiological parameters and oxygenation Physiological parameters}

A variety of physiological parameters are associated with adverse outcomes in patients with ARDS. In the landmark study of lower tidal volume ventilation for ARDS from the NIH ARDS Clinical Trials Network, inspiratory plateau pressures were significantly lower on days 1,3 , and 7 in the group treated with lower tidal volumes with lower mortality compared to the group treated with higher tidal volumes with higher mortality [5]. In the ALVEOLI study of two different levels of positive end expiratory pressure in ARDS, the alveolar-arterial oxygen gradient and inspiratory plateau pressure were good predictors for mortality in ARDS patients [22]. Furthermore, Nuckton et al. found that pulmonary dead-space fraction, which was calculated by the mean expired carbon dioxide fraction and was measured with a bedside metabolic monitor, was an independent risk factor for death [23]. Several subsequent studies have also reported that an elevated ratio of pulmonary dead space to tidal volume (VD /VT) within $24 \mathrm{~h}$ of onset of ARDS was associated with higher mortality [24, 25]. Elevated pulmonary dead space fraction likely reflects the extent of pulmonary microvascular thrombosis and injury or frank destruction of the pulmonary vascular bed, providing an important index of the severity of acute lung injury.

Beyond respiratory parameters, there is controversial data regarding the effect of right heart failure on the prognosis of ARDS. In a large multicenter cohort study in Europe, a higher ratio of right over left ventricular stroke work (RVSW/LVSW) at admission was independently associated with mortality [26]. However, in a randomized control study with a total of 145 ARDS patients receiving pulmonary artery catheters (PAC), there was no difference in 90-day mortality between patients with and without right ventricular failure (71 vs. $67 \%$, respectively) [27]. Again, it should be noted that the first study was done before the era of low tidal volume ventilation; ventilation with higher tidal volumes and higher pulmonary distending pressures may have had adverse effects on right heart function that were not as apparent in the more recent study. In another study in the low tidal volume ventilation era, Bull et al. demonstrated that pulmonary vascular dysfunction, which they defined as elevated transpulmonary gradient and pulmonary vascular resistance index measured by PAC in patients enrolled in the NIH ARDS Network Fluid and Catheter 
Treatment Trial [28], was an independent risk factor for 60-day mortality [29].

\section{Oxygenation}

It seems intuitive that the severity of hypoxemia should be associated with adverse outcomes in ARDS. However, over the past two decades, several studies have shown that the $\mathrm{PaO}_{2} / \mathrm{FiO}_{2}$ measured at the onset of ARDS is not an independent predictor of mortality [9, 30-34]. One possible explanation for the inability of initial $\mathrm{PaO}_{2} / \mathrm{FiO}_{2}$ to discriminate adverse outcomes in ARDS is that the $\mathrm{PaO}_{2} / \mathrm{FiO}_{2}$ varies depending on ventilator strategy. Indeed, manipulation of ventilator settings including tidal volume $(\mathrm{Vt})$ and positive end expiratory pressure (PEEP) can greatly influence the values of $\mathrm{PaO}_{2} / \mathrm{FiO}_{2}$ [35]. Since $\mathrm{PaO}_{2} / \mathrm{FiO}_{2}$ is so sensitive to ventilator settings, some investigators have asked whether the prognostic value of $\mathrm{PaO}_{2} / \mathrm{FiO}_{2}$ might improve with standardized ventilator settings. In a prospective, multicenter study of 452 ARDS patients with $\mathrm{PaO}_{2} / \mathrm{FiO}_{2}$ measured on standard ventilator settings of volume assist/ control mode, tidal volume $7 \mathrm{ml} / \mathrm{kg}$ PBW, inspiratory: expiratory time ratio (I:E) $<1: 1$, ventilator rate to maintain $\mathrm{PaCO}_{2}$ of 35-50 mmHg and $\mathrm{FiO}_{2}$ and PEEP settings applied in the following order: (1) $\mathrm{FiO}_{2} \geq 0.5$ with PEEP $\geq 5 \mathrm{cmH} 2 \mathrm{O}$, (2) $\mathrm{FiO}_{2} \geq 0.5$ with PEEP $\geq 10 \mathrm{cmH} 2 \mathrm{O}$, (3) $\mathrm{FiO}_{2}=1.0$ with PEEP $\geq 5 \mathrm{cmH} 2 \mathrm{O}$, and (4) $\mathrm{FiO}_{2}=1.0$ with PEEP $\geq 10 \mathrm{cmH} 2 \mathrm{O}$, risk stratification of ARDS was substantially improved. Of these settings, only the $\mathrm{PaO}_{2} /$ $\mathrm{FiO}_{2}$ ratio measured using $\mathrm{PEEP} \geq 10 \mathrm{cmH} 2 \mathrm{O}$ and $\mathrm{FiO} 2 \geq 0.5$ at $24 \mathrm{~h}$ after ARDS onset showed substantial improvement in risk stratification for short term ARDS mortality [36]. The finding is also consistent with analyses published with the Berlin ARDS definition; mortality prediction in ARDS was better when based not only on $\mathrm{PaO}_{2} / \mathrm{FiO}_{2}$, but also on PEEP level and the extent of lung infiltrates in chest radiograph [1]. Bone et al. showed that early improvement of $\mathrm{PaO}_{2} / \mathrm{FiO}_{2}$ with conventional therapy is a prognostic factor of better outcome in patients with ARDS [30]. In addition, the oxygenation response to the titration of PEEP or other ventilator settings, such as high-frequency oscillatory ventilation, may also be prognostically useful in ARDS $[37,38]$. Based on these findings, clinical trials that use the $\mathrm{PaO}_{2} / \mathrm{FiO}_{2}$ to select patients with more severe ARDS for enrollment have become more prevalent. A recent multicenter, prospective, randomized, controlled trial of prone positioning in patients with severe ARDS as defined by $\mathrm{PaO}_{2} / \mathrm{FiO}_{2}<150 \mathrm{mmHg}$ on PEEP of $\geq 5$ showed that prolonged prone-positioning sessions significantly decreased mortality in this patient group [6].

Unlike adults, children with ARDS are less likely to have complicated underlying diseases or other organ involvement. Thus, Flori et al. showed that the initial severity of arterial hypoxemia correlated well with ICU mortality in 328 children with ARDS [39]. Furthermore, Wong et al. showed that both a low $\mathrm{PaO}_{2} / \mathrm{FiO}_{2}$ ratio and a low $\mathrm{SpO}_{2} / \mathrm{FiO}_{2}$ were associated with poor outcomes in children with ARDS [40].

The Oxygenation Index (OI) is defined as the reciprocal of $\mathrm{PaO}_{2} / \mathrm{FiO}_{2}$ ratio multiplied by the mean airway pressure and was originally developed for evaluation of candidates for extracorporeal membrane oxygenation in pediatric respiratory failure [41]. The OI has also been evaluated as a clinical predictor in ARDS. In a study of 149 patients with ARDS undergoing lung protective ventilation, OI was superior to $\mathrm{PaO}_{2} / \mathrm{FiO}_{2}$ ratio, and was an independent predictor of mortality [42]. Similarly, a high OI at $24 \mathrm{~h}$ of ARDS was a risk factor for mortality [40], and improvement in OI during the first $24 \mathrm{~h}$ predicted a better outcome in pediatric patients with ARDS [43].

\section{Genetic polymorphisms and biomarkers Polymorphisms}

Several factors have made it challenging to determine the influence of genetic heterogeneity on clinical outcomes in ARDS. Foremost is the fact that ARDS is a complex clinical syndrome that involves multiple pathogenetic pathways and affects a diverse spectrum of patients who often have comorbid illnesses [3]. Additionally, it has been difficult to accrue sufficient patient numbers for identification and validation of genetic risk modifiers with relatively modest effect sizes. Nevertheless, a variety of genetic polymorphisms related to inflammation, innate immunity, epithelial cell function, and angiogenesis have been reported to be associated with adverse outcomes of ARDS $[15,44-48]$ as shown in Table 1 . Although a variety of common polymorphisms are associated with adverse outcomes in ARDS, such as homozygosity for the 4G allele of plasminogen activation inhibitor-1 (PAI-1) [49], others such as polymorphisms in the extracellular superoxide dismutase gene have been shown to have an association with better outcomes in ARDS [50]. In addition to the need for larger validation studies to confirm the observed associations, substantial additional research is needed to understand the functional impact of the various candidate polymorphisms on protein function and expression levels and how these functional changes contribute to alterations in ARDS outcomes.

\section{Biomarkers}

The pathophysiological hallmarks of ARDS are injury to the alveolar epithelial, microvascular endothelial barriers and alveolar-capillary membrane [51], with concomitant activation of inflammatory and coagulation pathways [52]. A variety of protein biomarkers have been studied for their prognostic value in ARDS. For discussion, we have categorized the most promising potential 
Table 1 Polymorphisms associated with mortality in ARDS patients

\begin{tabular}{|c|c|c|c|}
\hline Gene & No. of patients & Results & Reference \\
\hline DARC (rs2814778) & 132 & $17 \%$ increase in 60-day mortality & {$[15]$} \\
\hline NFE2L2 (rs6721961) & 750 & Increased 28-day mortality (OR 9.73) & {$[45]$} \\
\hline NAMPT (rs61330082) & 750 & Increased 28-day mortality (OR 4.37) & {$[45]$} \\
\hline ADIPOQ (rs208294) & 587 & Increased mortality (hazard ratio 2.61 & [46] \\
\hline ACE I/D polymorphism, DD type & 101 & Increase 28-day mortality (OR: 8.8) & [47] \\
\hline $\operatorname{VEGF}(-460 T+405 C+936 \mathrm{~T})$ & 394 & Increase 28-day mortality (OR: 2.89) & {$[48]$} \\
\hline GCCT haplotype of EC-SOD & 157 & Decreased 28-day mortality & [50] \\
\hline PAl-1 4G/5G polymorphism & 52 & Increase 28-day mortality (OR: 9.95) & [49] \\
\hline
\end{tabular}

$A C E$ angiotensin-converting enzyme, EC-SOD extracellular superoxide dismutase, DARC duffy antigen/receptor for chemokines, VEGF vascular endothelial growth factor

biomarkers into four categories [53], as shown in Table 2 and discussed below.

\section{Pulmonary Endothelium}

Injury to the pulmonary microvascular bed is a major pathogenetic feature of ARDS. Endothelial injury causes increased vascular permeability primarily at the level of the lung microcirculation, which in turn results in the accumulation of protein-rich pulmonary edema fluid in the alveolus [52]. Thus, various mediators of endothelial activation, injury and permeability have the potential to be prognostic indicators in ARDS.
Vascular endothelial growth factor (VEGF) promotes endothelial survival by inhibiting apoptosis in the alveolar capillary membrane. Abadie et al. reported that VEGF levels in lung tissue obtained by open lung biopsy from 29 ARDS patients were lower when comparing to a control group [54]. Furthermore, ARDS patients with elevated VEGF levels in lung epithelial lining fluid obtained by bronchoalveolar lavage or VEGF-receptor 2 measured in the serum had a better outcome $[55,56]$.

Angiopoietin-2 (Ang-2) is an angiogenic factor that promotes cell death and vascular destabilization. It is released from endothelial cells in response to endothelial activation by proinflammatory cytokines or local,

Table 2 Biomarkers associated with mortality in ARDS patients

\begin{tabular}{|c|c|c|c|c|}
\hline Categories & Plasma markers & $\begin{array}{l}\text { No. of } \\
\text { patients }\end{array}$ & Results & Reference \\
\hline \multicolumn{5}{|c|}{ Endothelium } \\
\hline & VEGF & 40 & $\begin{array}{l}\text { Elevated VEGF levels in ELF may predict a } \\
\text { better outcome }\end{array}$ & {$[55]$} \\
\hline & VEGF receptor-2 & 101 & Independently predictive of death & [56] \\
\hline & Angiopoietin-2 & 931 & Independently predictive of death & [59] \\
\hline & von Willebrand factor & 559 & Independently predictive of death & {$[60]$} \\
\hline \multicolumn{5}{|l|}{ Epithelium } \\
\hline & Surfactant protein-D & 565 & Independently predictive of death & {$[62]$} \\
\hline & ELF KL-6 & 32 & Predictive of death & [63] \\
\hline & RAGE & 676 & Predictive of death & {$[65]$} \\
\hline & Clara cell protein (CC-16) & 78 & Predictive of death & {$[69]$} \\
\hline \multicolumn{5}{|c|}{ Inflammation } \\
\hline & LTB4, IL-8 & $35,39,816$ & Predictive of death & {$[70-72]$} \\
\hline & $\mid \mathrm{L}-2, \mathrm{IL}-15$ & 34 & Predictive of death & {$[73]$} \\
\hline & Decoy receptor (DcR) 3 & & Predictive of death & {$[75]$} \\
\hline & $\begin{array}{l}\text { Ratio of Tregs to all CD4+ lymphocytes in bronchoalveolar } \\
\text { lavage (BAL) }\end{array}$ & 47 & Predictive of death & {$[79]$} \\
\hline \multicolumn{5}{|c|}{ Coagulation } \\
\hline & Protein C & 45,779 & Predictive of death & {$[83,84]$} \\
\hline & PAl-1 & 779 & Predictive of death & {$[84]$} \\
\hline
\end{tabular}


environmental factors such as hypoxia [57]. Circulating angiopoietin-2 levels are associated with permeability pulmonary edema, and the occurrence and severity of ARDS in patients with and without sepsis [58]. In 931 subjects with ARDS enrolled in a randomized trial of liberal versus conservative fluid management, higher baseline angiopoietin-2 levels were strongly associated with increased mortality in noninfection-related ARDS, but not in infection-related ARDS, indicating that plasma angiopoietin-2 has differential prognostic value for mortality depending on the presence or absence of infection as an ARDS risk factor [59].

Von Willebrand Factor antigen (VWF), a high molecular weight glycoprotein produced predominantly by endothelial cells, can be used as a marker of endothelial activation or injury. In a multicenter study of 559 patients with ARDS, higher plasma levels of VWF were independently associated with adverse outcomes, including mortality, duration of unassisted ventilation, and organ failures [60]. Taken together, the association of lower levels of VEGF and higher levels of Ang-2 and VWF suggests that the extent of endothelial injury is an important determinant of outcomes from ARDS.

\section{Pulmonary Epithelium}

Surfactant proteins (SP) are secreted primarily by alveolar epithelial type II pneumocytes, and leakage of surfactant proteins from the alveolar space into the circulation is a marker of lung epithelial injury [61]. Eisner et al. showed that baseline SP-D plasma levels were associated with increased risk of death in 565 patients with ARDS. In addition, a low tidal volume protective ventilatory strategy $(6 \mathrm{ml} / \mathrm{kg})$ had no effect on the rise in plasma SP-A levels but attenuated the rise in plasma SP-D levels [62].

KL-6 is a mucin-like glycoprotein expressed on the surface of alveolar type II cells. Damage to pulmonary epithelial cells allows KL6 to diffuse into the pulmonary epithelial lining fluid (ELF). In a study of 32 patients with ARDS, ELF was collected using a bronchoscopic microsampling procedure, showing that KL-6 levels in ELF, but not serum, measured during the early period after the diagnosis were useful for predicting mortality [63].

The receptor for advanced glycation end products (RAGE), a member of the immunoglobulin superfamily that acts as a multi-ligand receptor, has been identified as a marker of alveolar type I cell injury [64]. In a multicenter study of 676 patients with ARDS enrolled in a randomized controlled trial of lower tidal volume ventilation, higher baseline plasma RAGE was associated with increased severity of lung injury and mortality (OR 1.38) [65].

Clara cell protein (CC-16), an inhibitor of phospholipase A2 activity produced by distal bronchiolar epithelial cells, has been shown to have a protective and immunomodulatory role in acute lung injury [66]. In a retrospective study of 22 patients with ventilatorassociated pneumonia, levels of $\mathrm{CC}-16$ increased 2 days before ARDS diagnosis [67]. However, Kropski et al. showed that levels of CC-16 in plasma or edema fluid were lower in ARDS than in critically ill controls with cardiogenic pulmonary edema [68]. In a prospective multicenter observational study from Quebec Critical Care Network, a higher initial CC-16 serum level was associated with increased risk of death in 78 adult ARDS patients [69]. Different time points for obtaining the CC-16 and variable severity of lung injury may be potential explanations for these conflicting findings.

\section{Inflammatory mediators}

Inflammation is fundamental to the pathogenesis of ARDS and a variety of inflammatory biomarkers have been assessed for prognostic utility. Among the cytokines, plasma leukotriene (LT) B4, interleukin (IL)-8, and IL-6 have been recognized as useful prognostic indices in patients with early phase ARDS [70-72]. In addition, serum IL-2 and IL-15 levels had shown to be associated with mortality in patients with ARDS [73].

Decoy receptor (DcR) 3, belonging to the tumor necrosis factor receptor superfamily, is an antiapoptotic soluble receptor considered to play a role in immune modulation [74]. In a study of 88 ARDS patients, high plasma DcR3 levels correlated with development of multiple-organ dysfunction and independently predicted 28-day mortality [75].

T-regulatory cells (Tregs), a subset of CD4+ lymphocytes that express CD25 (IL-2 receptor $\boldsymbol{\alpha}$ ) as well as the transcription factor Forkhead box protein 3 (Foxp3) on their surface, have been shown to suppress inflammatory, allergic, and autoimmune disorders [76, 77]. D'Alessio et al. identified that CD4 + CD25 + Foxp3+ Tregs serve a fundamental role in mediating resolution of lung injury by modulating innate immune responses [78]. In a prospective study of 47 patients with ARDS, the ratio of Tregs to all CD4+ lymphocytes in bronchoalveolar lavage (BAL) was shown to be an independent prognostic factor for 30-day mortality [79].

C-reactive protein (CRP) has been studied as a marker of systemic inflammation and outcome in a number of diseases. In a prospective study of 177 patients with ARDS, increasing plasma levels of CRP within $48 \mathrm{~h}$ of ARDS onset were associated with a better outcome, implying that CRP is not solely a marker of systemic inflammation [80]. From this same study cohort, Rivara et al. further showed that elevated cardiac troponin $\mathrm{T}$ (cTnT), a biomarker of cardiac necrosis, was associated with worsened clinical outcomes and certain echocardiographic abnormalities in patients with ARDS [81].

\section{Coagulation}


Protein $\mathrm{C}$ plays an active role in modulating severe systemic inflammatory processes such as sepsis, and trauma via its anticoagulant and anti-inflammatory properties [82]. The first human study regarding protein $\mathrm{C}$ in ARDS, which enrolled 45 patients, showed that lower levels of plasma protein $\mathrm{C}$ were associated with worse clinical outcomes [83]. Later, in a larger multicenter study of a protective ventilatory strategy in 779 patients with ARDS, lower plasma levels of protein $C$ were an independent risk factor for mortality and adverse clinical outcomes [84]. Based on these findings, Cornet et al. conducted a randomized control trial of intravenous recombinant human activated protein $C$ for 4 days, finding that it did not improve outcomes in patients with ARDS [85]. Similarly, Liu et al. also showed that activated protein $\mathrm{C}$ did not improve outcomes from ARDS in a double-blind randomized control trial [86].

Plasminogen activator inhibitor-1 (PAI-1) impairs fibrinolysis by inhibiting tissue plasminogen activator (tPA) and urokinase (uPA). Ware et al. showed that increased plasma levels of PAI-1 are independent risk factors for mortality in 779 patients with ARDS and that the combination of low protein $\mathrm{C}$ levels with high PAI-1 levels portended a particularly poor prognosis [84].

Although there have been a number of biological markers investigated for predicting clinical outcomes in ARDS, no single clinical or biological marker is able to predict the outcome accurately. Thus, Ware et al. combined eight biological markers and clinical variables to predict mortality in 549 patients with ARDS from an NIH ARDS Network clinical trial of two levels of positive end-expiratory pressure in ARDS. In that study, a combination of clinical predictors and biomarkers had the best performance for predicting mortality in patients with ARDS compared to clinical predictors or biomarkers alone [13].

\section{Scoring systems}

For describing the severity-of-illness and constructing risk-prediction models in general ICU populations, many scoring systems have been developed, such as the Acute Physiology and Chronic Health Evaluation (APACHE) scores [87-89], the Simplified Acute Physiology Scores [90] and Sequential Organ Failure Assessment (SOFA) scoring [91]. APACHE II score is not only accurate for predicting outcomes in general ICU patients, but also in patients with ARDS $[69,73]$. In addition, the APACHE IV score, the RIFLE score (Risk of renal failure, Injury to the kidney, Failure of kidney function, Loss of kidney function, and End-stage renal failure) [92], and GOCA score (Gas exchange, Organ failure, Cause, Associated disease) [93] have all been proved to have prognostic value in predicting mortality in patients with ARDS.
In terms of scoring systems for predicting mortality specifically in ARDS patients, the most commonly used is the Lung Injury Score (LIS), proposed in 1988 by Murray and colleagues [94]. The Lung Injury Score is based on four components: 1) chest radiograph; 2) hypoxemia score; 3 ) PEEP; and 4) static compliance of respiratory system. Although it was not originally intended as a risk prediction tool, it has been widely used to assess ARDS severity in clinical studies. However, some studies showed that LIS was not independently associated with in-hospital mortality in ARDS patients $[8,11,13]$ when ARDS was defined by AECC criteria [2]. By contrast, in a multi-ICU cohort study with 550 ARDS patients diagnosed by Berlin definition, the LIS was associated with increased in-hospital morbidity and mortality [95].

\section{Conclusions}

ARDS is a complex and heterogeneous syndrome. A variety of clinical and biomarker parameters can be used for risk prediction and prognostication. Discovery of prognostic factors for ARDS has enriched our understanding of the pathogenesis of this complex clinical syndrome and has impacted clinical trial design, risk assessment and accurate diagnosis of the syndrome. In this review, we categorized the prognostic factors into four areas including (1) clinical characteristics (2) physiological parameters and oxygenation (3) genetic polymorphisms and biomarkers (4) scoring systems. In terms of clinical characteristics, age and severity of illness scores remain the most robust predictors of outcome while blood type, race and ethnicity may be novel predictors of death in ARDS that require further validation. Pulmonary dead space, ratio of right over left ventricular stroke work, $\mathrm{PaO}_{2} / \mathrm{FiO}_{2}$ ratio, and oxygenation index are proven to be independent predictors of mortality. A number of genetic polymorphisms have been shown to be associated with mortality in ARDS, in genes including angiotensin-converting enzyme, extracellular superoxide dismutase, duffy antigen/receptor for chemokines, and vascular endothelial growth factor. A variety of biomarkers involved in the pathogenesis of endothelial and epithelial injury, inflammatory response and coagulation have been explored. Scoring systems such as APACHE II, GOCA, LIS, and RIFLE score are reliable in predicting mortality in ARDS. Finally, prognostic factors differ for predicting short-term and long-term outcomes, and may differ depending on treatment including low tidal volume, prone position or ECMO intervention. Thus, recent changes in definitions [1] and ventilatory strategies [9] should be taken into account in interpreting older prognostic studies that preceded the low tidal volume era.

Based on the prognostic factors mentioned above, we may better determine subphenotypes of ARDS. Incorporating these distinctions into clinical trial design may 
allow more effective treatment selection for a particular ARDS phenotype in the future. For example, Calfee et al. showed that ARDS patients with a hyperinflammatory subphenotype identified by latent class analysis of a combination of clinical characteristics and plasma biomarkers had worse clinical outcomes and differential responses to ventilator interventions in two large cohorts [96]. Briel et al. showed that patients with moderate or severe ARDS, but not mild ARDS had an improved hospital survival when using a higher level of PEEP [97]. Guérin et al. found that only in patients with severe ARDS, but not moderate or mild ARDS, early application of prolonged prone-positioning sessions significantly decreased 28-day and 90-day mortality [6]. These studies illustrate the potential for use of prognostic factors including clinical factors such as oxygenation and biological markers for better selecting patients for enrollment in ARDS clinical trials.

\section{Competing interests}

The authors declare that they have no competing interests.

\section{Authors' contributions}

The paper was written by WC and LW. Both authors read and approved the final manuscript.

\section{Acknowledgements}

This work was supported by grants from the National Institutes of Health $\mathrm{HL}$ 103836 and HL112656.

\section{Author details}

${ }^{1}$ Division of Allergy, Pulmonary, and Critical Care Medicine, Department of Medicine, Vanderbilt University School of Medicine, Nashville, USA. ${ }^{2}$ Division of Pulmonary and Critical Care Medicine, Chiayi Christian Hospital, 600 Chia-Yi, Taiwan. ${ }^{3}$ Department of Life Science, National Chung Hsing University, Taichung, Taiwan. ${ }^{4}$ Department of Respiratory Therapy, China Medical University, Taichung, Taiwan. ${ }^{5}$ Department of Pathology, Microbiology and Immunology, Vanderbilt University School of Medicine, Nashville, USA.

Received: 30 January 2015 Accepted: 19 June 2015

Published online: 02 July 2015

\section{References}

1. Ranieri VM, Rubenfeld GD, Thompson BT, Ferguson ND, Caldwell E, Fan E, et al. Acute respiratory distress syndrome: the Berlin Definition. JAMA. 2012;307(23):2526-33. doi:10.1001/jama.2012.5669.

2. Bernard GR, Artigas A, Brigham KL, Carlet J, Falke K, Hudson L, et al. The American-European Consensus Conference on ARDS. Definitions, mechanisms, relevant outcomes, and clinical trial coordination. Am J Respir Crit Care Med. 1994;149(3 Pt 1):818-24. doi:10.1164/ajrccm.149.3.7509706.

3. Matthay MA, Ware LB, Zimmerman GA. The acute respiratory distress syndrome. J Clin Invest. 2012;122(8):2731-40. doi:10.1172/JCI60331.

4. Schmickl CN, Biehl M, Wilson GA, Gajic O. Comparison of Hospital Mortality and Long-Term Survival in Patients with Acute Lung Injury (ALI)/Acute Respiratory Distress Syndrome (ARDS) versus Cardiogenic Pulmonary Edema (CPE). Chest. 2014. doi:10.1378/chest.14-1371.

5. Ventilation with lower tidal volumes as compared with traditional tidal volumes for acute lung injury and the acute respiratory distress syndrome. The Acute Respiratory Distress Syndrome Network. N Engl J Med. 2000;342(18):1301-8. 10.1056/NEJM200005043421801.

6. Guerin C, Reignier J, Richard JC, Beuret P, Gacouin A, Boulain T, et al. Prone positioning in severe acute respiratory distress syndrome. N Engl J Med. 2013;368(23):2159-68. doi:10.1056/NEJMoa1214103.

7. Doyle RL, Szaflarski N, Modin GW, Wiener-Kronish JP, Matthay MA. Identification of patients with acute lung injury. Predictors of mortality. Am
J Respir Crit Care Med. 1995;152(6 Pt 1):1818-24. doi:10.1164/ ajrccm.152.6.8520742.

8. Zilberberg MD, Epstein SK. Acute lung injury in the medical ICU: comorbid conditions, age, etiology, and hospital outcome. Am J Respir Crit Care Med. 1998;157(4 Pt 1):1159-64. doi:10.1164/ajrccm.157.4.9704088.

9. Brun-Buisson C, Minelli C, Bertolini G, Brazzi L, Pimentel J, Lewandowski K, et al. Epidemiology and outcome of acute lung injury in European intensive care units. Results from the ALIVE study. Intensive Care Med. 2004;30(1):5161. doi:10.1007/s00134-003-2022-6.

10. Luhr OR, Antonsen K, Karlsson M, Aardal S, Thorsteinsson A, Frostell CG, et al. Incidence and mortality after acute respiratory failure and acute respiratory distress syndrome in Sweden, Denmark, and Iceland. The ARF Study Group. Am J Respir Crit Care Med. 1999;159(6):1849-61. doi:10.1164/ ajrccm.159.6.9808136.

11. Monchi M, Bellenfant F, Cariou A, Joly LM, Thebert D, Laurent I, et al. Early predictive factors of survival in the acute respiratory distress syndrome. A multivariate analysis. Am J Respir Crit Care Med. 1998;158(4):1076-81. doi:10.1164/ajrccm.158.4.9802009.

12. Calfee CS, Ware LB, Glidden DV, Eisner MD, Parsons PE, Thompson BT, et al. Use of risk reclassification with multiple biomarkers improves mortality prediction in acute lung injury. Crit Care Med. 2011;39(4):711-7. doi:10.1097/ CCM.0b013e318207ec3c.

13. Krafft $P$, Fridrich $P$, Pernerstorfer $T$, Fitzgerald RD, Koc D, Schneider $B$, et al. The acute respiratory distress syndrome: definitions, severity and clinical outcome. An analysis of 101 clinical investigations. Intensive Care Med. 1996;22(6):519-29.

14. Erickson SE, Shlipak MG, Martin GS, Wheeler AP, Ancukiewicz M, Matthay MA, et al. Racial and ethnic disparities in mortality from acute lung injury. Crit Care Med. 2009;37(1):1-6. doi:10.1097/CCM.0b013e31819292ea.

15. Kangelaris KN, Sapru A, Calfee CS, Liu KD, Pawlikowska L, Witte JS, et al. The association between a Darc gene polymorphism and clinical outcomes in African American patients with acute lung injury. Chest. 2012;141(5):1160-9. doi:10.1378/chest.11-1766.

16. Lemos-Filho LB, Mikkelsen ME, Martin GS, Dabbagh O, Adesanya A, Gentile $\mathrm{N}$, et al. Sex, race, and the development of acute lung injury. Chest. 2013;143(4):901-9. doi:10.1378/chest.12-1118

17. Reilly JP, Meyer NJ, Shashaty MG, Feng R, Lanken PN, Gallop R, et al. ABO blood type $A$ is associated with increased risk of ARDS in whites following both major trauma and severe sepsis. Chest. 2014;145(4):753-61. doi:10.1378/chest.13-1962.

18. Koh GC, Vlaar AP, Hofstra JJ, de Jong HK, van Nierop S, Peacock SJ, et al. In the critically ill patient, diabetes predicts mortality independent of statin therapy but is not associated with acute lung injury: a cohort study. Crit Care Med. 2012;40(6):1835-43. doi:10.1097/CCM.0b013e31824e1696.

19. Yu S, Christiani DC, Thompson BT, Bajwa EK, Gong MN. Role of diabetes in the development of acute respiratory distress syndrome. Crit Care Med. 2013;41(12):2720-32. doi:10.1097/CCM.0b013e318298a2eb.

20. Wang CY, Calfee CS, Paul DW, Janz DR, May AK, Zhuo H, et al. One-year mortality and predictors of death among hospital survivors of acute respiratory distress syndrome. Intensive Care Med. 2014;40(3):388-96. doi:10.1007/s00134-013-3186-3.

21. Schmidt M, Zogheib E, Roze H, Repesse X, Lebreton G, Luyt CE, et al. The PRESERVE mortality risk score and analysis of long-term outcomes after extracorporeal membrane oxygenation for severe acute respiratory distress syndrome. Intensive Care Med. 2013;39(10):1704-13. doi:10.1007/s00134013-3037-2.

22. Brower RG, Lanken PN, Maclntyre N, Matthay MA, Morris A, Ancukiewicz M, et al. Higher versus lower positive end-expiratory pressures in patients with the acute respiratory distress syndrome. N Engl J Med. 2004;351(4):327-36. doi:10.1056/NEJMoa032193.

23. Nuckton TJ, Alonso JA, Kallet RH, Daniel BM, Pittet JF, Eisner MD, et al. Pulmonary dead-space fraction as a risk factor for death in the acute respiratory distress syndrome. N Engl J Med. 2002;346(17):1281-6. doi:10.1056/NEJMoa012835

24. Kallet RH, Alonso JA, Pittet JF, Matthay MA. Prognostic value of the pulmonary dead-space fraction during the first 6 days of acute respiratory distress syndrome. Respir Care. 2004;49(9):1008-14.

25. Raurich JM, Vilar M, Colomar A, Ibanez J, Ayestaran I, Perez-Barcena J, et al. Prognostic value of the pulmonary dead-space fraction during the early and intermediate phases of acute respiratory distress syndrome. Respir Care. 2010;55(3):282-7. 
26. Squara P, Dhainaut JF, Artigas A, Carlet J. Hemodynamic profile in severe ARDS: results of the European Collaborative ARDS Study. Intensive Care Med. 1998;24(10):1018-28.

27. Osman D, Monnet X, Castelain V, Anguel N, Warszawski J, Teboul JL, et al. Incidence and prognostic value of right ventricular failure in acute respiratory distress syndrome. Intensive Care Med. 2009;35(1):69-76. doi:10.1007/s00134-008-1307-1.

28. National Heart L. Blood Institute Acute Respiratory Distress Syndrome Clinical Trials N, Wiedemann HP, Wheeler AP, Bernard GR, Thompson BT et al. Comparison of two fluid-management strategies in acute lung injury. $\mathrm{N}$ Engl J Med. 2006;354(24):2564-75. doi:10.1056/NEJMoa062200.

29. Bull TM, Clark B, McFann K, Moss M. National Institutes of Health/National Heart L, Blood Institute AN. Pulmonary vascular dysfunction is associated with poor outcomes in patients with acute lung injury. Am J Respir Crit Care Med. 2010;182(9):1123-8. doi:10.1164/rccm.201002-02500C.

30. Bone RC, Maunder R, Slotman G, Silverman H, Hyers TM, Kerstein MD, et al. An early test of survival in patients with the adult respiratory distress syndrome. The PaO2/Flo2 ratio and its differential response to conventional therapy. Prostaglandin E1 Study Group. Chest. 1989;96(4):849-51.

31. Sloane PJ, Gee MH, Gottlieb JE, Albertine KH, Peters SP, Burns JR, et al. A multicenter registry of patients with acute respiratory distress syndrome. Physiology and outcome. Am Rev Respir Dis. 1992;146(2):419-26. doi:10.1164/ajrccm/146.2.419.

32. Knaus WA, Sun X, Hakim RB, Wagner DP. Evaluation of definitions for adult respiratory distress syndrome. Am J Respir Crit Care Med. 1994;150(2):311-7. doi:10.1164/ajrccm.150.2.8049808.

33. Luhr OR, Karlsson M, Thorsteinsson A, Rylander C, Frostell CG. The impact of respiratory variables on mortality in non-ARDS and ARDS patients requiring mechanical ventilation. Intensive Care Med. 2000;26(5):508-17.

34. Bersten AD, Edibam C, Hunt T, Moran J. Australian, New Zealand Intensive Care Society Clinical Trials G. Incidence and mortality of acute lung injury and the acute respiratory distress syndrome in three Australian States. Am J Respir Crit Care Med. 2002;165(4):443-8. doi:10.1164/ajrccm.165.4.2101124.

35. Ferguson ND, Kacmarek RM, Chiche JD, Singh JM, Hallett DC, Mehta S, et al. Screening of ARDS patients using standardized ventilator settings: influence on enrollment in a clinical trial. Intensive Care Med. 2004;30(6):1111-6. doi:10.1007/s00134-004-2163-2.

36. Villar J, Perez-Mendez L, Blanco J, Anon JM, Blanch L, Belda J, et al. A universal definition of ARDS: the $\mathrm{PaO} 2 / \mathrm{FiO} 2$ ratio under a standard ventilatory setting-a prospective, multicenter validation study. Intensive Care Med. 2013;39(4):583-92. doi:10.1007/s00134-012-2803-x.

37. Goligher EC, Kavanagh BP, Rubenfeld GD, Adhikari NK, Pinto R, Fan E, et al. Oxygenation Response to PEEP Predicts Mortality in ARDS: A Secondary Analysis of the LOVS and ExPress Trials. Am J Respir Crit Care Med. 2014 doi:10.1164/rccm.201404-06880C.

38. Camporota L, Sherry T, Smith J, Lei K, McLuckie A, Beale R. Physiological predictors of survival during high-frequency oscillatory ventilation in adults with acute respiratory distress syndrome. Crit Care. 2013;17(2):R40. doi:10.1186/cc12550

39. Flori HR, Glidden DV, Rutherford GW, Matthay MA. Pediatric acute lung injury: prospective evaluation of risk factors associated with mortality. Am J Respir Crit Care Med. 2005;171(9):995-1001. doi:10.1164/rccm.200404-5440C.

40. Wong JJ, Loh TF, Testoni D, Yeo JG, Mok YH, Lee JH. Epidemiology of pediatric acute respiratory distress syndrome in singapore: risk factors and predictive respiratory indices for mortality. Front Pediatr. 2014;2:78. doi:10.3389/fped.2014.00078.

41. Ortiz RM, Cilley RE, Bartlett RH. Extracorporeal membrane oxygenation in pediatric respiratory failure. Pediatr Clin N Am. 1987;34(1):39-46.

42. Seeley E, McAuley DF, Eisner M, Miletin M, Matthay MA, Kallet RH. Predictors of mortality in acute lung injury during the era of lung protective ventilation. Thorax. 2008;63(11):994-8. doi:10.1136/thx.2007.093658.

43. Relvas MS, Silver PC, Sagy M. Prone positioning of pediatric patients with ARDS results in improvement in oxygenation if maintained $>12 \mathrm{~h}$ daily. Chest. 2003;124(1):269-74.

44. Jerng JS, Yu CJ, Wang HC, Chen KY, Cheng SL, Yang PC. Polymorphism of the angiotensin-converting enzyme gene affects the outcome of acute respiratory distress syndrome. Crit Care Med. 2006;34(4):1001-6. doi:10.1097/ 01.CCM.0000206107.92476.39

45. O'Mahony DS, Glavan BJ, Holden TD, Fong C, Black RA, Rona G, et al. Inflammation and immune-related candidate gene associations with acute lung injury susceptibility and severity: a validation study. PLoS One. 2012;7(12):e51104. doi:10.1371/journal.pone.0051104.

46. Ahasic AM, Zhao Y, Su L, Sheu CC, Thompson BT, Christiani DC. Adiponectin gene polymorphisms and acute respiratory distress syndrome susceptibility and mortality. PLoS One. 2014;9(2):e89170. doi:10.1371/ journal.pone.0089170.

47. Lu XM, Chen GJ, Yang Y, Qiu HB. Angiotensin-converting enzyme polymorphism affects outcome of local Chinese with acute lung injury. Respir Med. 2011;105(10):1485-90. doi:10.1016/j.rmed.2011.06.009.

48. Zhai R, Gong MN, Zhou W, Thompson TB, Kraft P, Su L, et al. Genotypes and haplotypes of the VEGF gene are associated with higher mortality and lower VEGF plasma levels in patients with ARDS. Thorax. 2007;62(8):718-22. doi:10.1136/thx.2006.069393.

49. Tsangaris I, Tsantes A, Bonovas S, Lignos M, Kopterides P, Gialeraki A, et al. The impact of the PAl-1 4G/5G polymorphism on the outcome of patients with ALI/ARDS. Thromb Res. 2009;123(6):832-6. doi:10.1016/ j.thromres.2008.07.018.

50. Arcaroli JJ, Hokanson JE, Abraham E, Geraci M, Murphy JR, Bowler RP, et al Extracellular superoxide dismutase haplotypes are associated with acute lung injury and mortality. Am J Respir Crit Care Med. 2009;179(2):105-12. doi:10.1164/rccm.200710-15660C.

51. Ware LB, Matthay MA. The acute respiratory distress syndrome. N Engl J Med. 2000;342(18):1334-49. doi:10.1056/NEJM200005043421806.

52. Matthay MA, Zemans RL. The acute respiratory distress syndrome: pathogenesis and treatment. Annu Rev Pathol. 2011;6:147-63. doi:10.1146/ annurev-pathol-011110-130158.

53. Janz DR, Ware LB. Biomarkers of ALI/ARDS: pathogenesis, discovery, and relevance to clinical trials. Semin Respir Crit Care Med. 2013;34(4):537-48. doi:10.1055/s-0033-1351124.

54. Abadie Y, Bregeon F, Papazian L, Lange F, Chailley-Heu B, Thomas P, et al. Decreased VEGF concentration in lung tissue and vascular injury during ARDS. Eur Respir J. 2005;25(1):139-46. doi:10.1183/09031936.04.00065504.

55. Koh H, Tasaka S, Hasegawa N, Asano K, Kotani T, Morisaki H, et al. Vascular endothelial growth factor in epithelial lining fluid of patients with acute respiratory distress syndrome. Respirology. 2008;13(2):281-4. doi:10.1111/ j.1440-1843.2007.01193.x

56. Wada T, Jesmin S, Gando S, Yanagida Y, Mizugaki A, Sultana SN, et al. The role of angiogenic factors and their soluble receptors in acute lung injury (ALI)/ acute respiratory distress syndrome (ARDS) associated with critical illness. J Inflamm. 2013;10(1):6. doi:10.1186/1476-9255-10-6.

57. Fiedler $U$, Augustin HG. Angiopoietins: a link between angiogenesis and inflammation. Trends Immunol. 2006;27(12):552-8. doi:10.1016/ j.it.2006.10.004.

58. van der Heijden M, van Nieuw Amerongen GP, Koolwijk P, van Hinsbergh WW, Groeneveld AB. Angiopoietin-2, permeability oedema, occurrence and severity of ALI/ARDS in septic and non-septic critically ill patients. Thorax. 2008;63(10):903-9. doi:10.1136/thx.2007.087387.

59. Calfee CS, Gallagher D, Abbott J, Thompson BT, Matthay MA, Network NA. Plasma angiopoietin-2 in clinical acute lung injury: prognostic and pathogenetic significance. Crit Care Med. 2012;40(6):1731-7. doi:10.1097/ CCM.0b013e3182451c87.

60. Ware LB, Eisner MD, Thompson BT, Parsons PE, Matthay MA. Significance of von Willebrand factor in septic and nonseptic patients with acute lung injury. Am J Respir Crit Care Med. 2004;170(7):766-72. doi:10.1164/ rccm.200310-14340C.

61. Greene KE, Wright JR, Steinberg KP, Ruzinski JT, Caldwell E, Wong WB, et al. Serial changes in surfactant-associated proteins in lung and serum before and after onset of ARDS. Am J Respir Crit Care Med. 1999;160(6):1843-50. doi:10.1164/ajrccm.160.6.9901117.

62. Eisner MD, Parsons P, Matthay MA, Ware L, Greene K. Acute Respiratory Distress Syndrome N. Plasma surfactant protein levels and clinical outcomes in patients with acute lung injury. Thorax. 2003;58(11):983-8.

63. Kondo T, Hattori N, Ishikawa N, Murai H, Haruta Y, Hirohashi N, et al. KL-6 concentration in pulmonary epithelial lining fluid is a useful prognostic indicator in patients with acute respiratory distress syndrome. Respir Res. 2011;12:32. doi:10.1186/1465-9921-12-32.

64. Uchida T, Shirasawa M, Ware LB, Kojima K, Hata Y, Makita K, et al. Receptor for advanced glycation end-products is a marker of type I cell injury in acute lung injury. Am J Respir Crit Care Med. 2006;173(9):1008-15. doi:10.1164/rccm.200509-14770C 
65. Calfee CS, Ware LB, Eisner MD, Parsons PE, Thompson BT, Wickersham N, et al. Plasma receptor for advanced glycation end products and clinical outcomes in acute lung injury. Thorax. 2008;63(12):1083-9. doi:10.1136/ thx.2008.095588.

66. Jorens PG, Sibille Y, Goulding NJ, van Overveld FJ, Herman AG, Bossaert L, et al. Potential role of Clara cell protein, an endogenous phospholipase A2 inhibitor, in acute lung injury. Eur Respir J. 1995;8(10):1647-53.

67. Determann RM, Millo JL, Waddy S, Lutter R, Garrard CS, Schultz MJ. Plasma CC16 levels are associated with development of ALI/ARDS in patients with ventilator-associated pneumonia: a retrospective observational study. BMC Pulm Med. 2009;9:49. doi:10.1186/1471-2466-9-49.

68. Kropski JA, Fremont RD, Calfee CS, Ware LB. Clara cell protein (CC16), a marker of lung epithelial injury, is decreased in plasma and pulmonary edema fluid from patients with acute lung injury. Chest. 2009;135(6):1440-7. doi:10.1378/chest.08-2465.

69. Lesur O, Langevin S, Berthiaume Y, Legare M, Skrobik Y, Bellemare JF, et al. Outcome value of Clara cell protein in serum of patients with acute respiratory distress syndrome. Intensive Care Med. 2006;32(8):1167-74. doi:10.1007/s00134-006-0235-1.

70. Amat M, Barcons M, Mancebo J, Mateo J, Oliver A, Mayoral JF, et al. Evolution of leukotriene B4, peptide leukotrienes, and interleukin-8 plasma concentrations in patients at risk of acute respiratory distress syndrome and with acute respiratory distress syndrome: mortality prognostic study. Crit Care Med. 2000;28(1):57-62.

71. Lin WC, Lin CF, Chen CL, Chen CW, Lin YS. Prediction of outcome in patients with acute respiratory distress syndrome by bronchoalveolar lavage inflammatory mediators. Exp Biol Med. 2010;235(1):57-65. doi:10.1258/ ebm.2009.009256.

72. Parsons PE, Eisner MD, Thompson BT, Matthay MA, Ancukiewicz M, Bernard $\mathrm{GR}$, et al. Lower tidal volume ventilation and plasma cytokine markers of inflammation in patients with acute lung injury. Crit Care Med. 2005;33(1):16. discussion 230-2.

73. Agouridakis P, Kyriakou D, Alexandrakis MG, Perisinakis K, Karkavitsas N, Bouros D. Association between increased levels of IL-2 and IL-15 and outcome in patients with early acute respiratory distress syndrome. Eur J Clin Investig. 2002;32(11):862-7.

74. Pitti RM, Marsters SA, Lawrence DA, Roy M, Kischkel FC, Dowd P, et al. Genomic amplification of a decoy receptor for Fas ligand in lung and colon cancer. Nature. 1998;396(6712):699-703. doi:10.1038/25387.

75. Chen CY, Yang KY, Chen MY, Chen HY, Lin MT, Lee YC, et al. Decoy receptor 3 levels in peripheral blood predict outcomes of acute respiratory distress syndrome. Am J Respir Crit Care Med. 2009;180(8):751-60. doi:10.1164/ rccm.200902-02220C.

76. Aggarwal NR, D'Alessio FR, Tsushima K, Sidhaye VK, Cheadle C, Grigoryev $\mathrm{DN}$, et al. Regulatory $T$ cell-mediated resolution of lung injury: identification of potential target genes via expression profiling. Physiol Genomics. 2010:41(2):109-19. doi:10.1152/physiolgenomics.00131.2009.

77. Wilczynski JR, Radwan M, Kalinka J. The characterization and role of regulatory T cells in immune reactions. Front Biosci. 2008;13:2266-74.

78. D'Alessio FR, Tsushima K, Aggarwal NR, West EE, Willett MH, Britos MF, et al. CD4 + CD25 + Foxp3+ Tregs resolve experimental lung injury in mice and are present in humans with acute lung injury. J Clin Invest. 2009;119(10):2898-913. doi:10.1172/JCl36498.

79. Adamzik M, Broll J, Steinmann J, Westendorf AM, Rehfeld I, Kreissig C, et al. An increased alveolar CD4 + CD25 + Foxp3 + T-regulatory cell ratio in acute respiratory distress syndrome is associated with increased 30-day mortality. Intensive Care Med. 2013;39(10):1743-51. doi:10.1007/s00134-013-3036-3.

80. Bajwa EK, Khan UA, Januzzi JL, Gong MN, Thompson BT, Christiani DC. Plasma C-reactive protein levels are associated with improved outcome in ARDS. Chest. 2009;136(2):471-80. doi:10.1378/chest.08-2413.

81. Rivara MB, Bajwa EK, Januzzi JL, Gong MN, Thompson BT, Christiani DC. Prognostic significance of elevated cardiac troponin-T levels in acute respiratory distress syndrome patients. PLoS One. 2012;7(7):e40515. doi:10.1371/journal.pone.0040515.

82. Christiaans SC, Wagener BM, Esmon CT, Pittet JF. Protein C and acute inflammation: a clinical and biological perspective. Am J Physiol Lung Cell Mol Physiol. 2013;305(7):L455-66. doi:10.1152/ajplung.00093.2013.

83. Matthay MA, Ware LB. Plasma protein C levels in patients with acute lung injury: prognostic significance. Crit Care Med. 2004;32(5 Suppl):S229-32.

84. Ware LB, Matthay MA, Parsons PE, Thompson BT, Januzzi JL, Eisner MD, et al. Pathogenetic and prognostic significance of altered coagulation and fibrinolysis in acute lung injury/acute respiratory distress syndrome. Crit Care Med. 2007:35(8):1821-8. doi:10.1097/01.CCM.0000221922.08878.49.

85. Cornet AD, Groeneveld AB, Hofstra JJ, Vlaar AP, Tuinman PR, van Lingen A, et al. Recombinant human activated protein $C$ in the treatment of acute respiratory distress syndrome: a randomized clinical trial. PLoS One. 2014;9(3):e90983. doi:10.1371/journal.pone.0090983.

86. Liu KD, Levitt J, Zhuo H, Kallet RH, Brady S, Steingrub J, et al. Randomized clinical trial of activated protein $\mathrm{C}$ for the treatment of acute lung injury. Am J Respir Crit Care Med. 2008;178(6):618-23. doi:10.1164/rccm.2008034190C.

87. Knaus WA, Draper EA, Wagner DP, Zimmerman JE. APACHE II: a severity of disease classification system. Crit Care Med. 1985;13(10):818-29.

88. Knaus WA, Wagner DP, Draper EA, Zimmerman JE, Bergner M, Bastos PG, et al. The APACHE III prognostic system. Risk prediction of hospital mortality for critically ill hospitalized adults. Chest. 1991;100(6):1619-36.

89. Zimmerman JE, Kramer AA, MCNair DS, Malila FM. Acute Physiology and Chronic Health Evaluation (APACHE) IV: hospital mortality assessment for today's critically ill patients. Crit Care Med. 2006;34(5):1297-310. doi:10.1097/ 01.CCM.0000215112.84523.F0.

90. Le Gall JR, Lemeshow S, Saulnier F. A new Simplified Acute Physiology Score (SAPS II) based on a European/North American multicenter study. JAMA. 1993;270(24):2957-63.

91. Vincent JL, Moreno R, Takala J, Willatts S, De Mendonca A, Bruining H, et al. The SOFA (Sepsis-related Organ Failure Assessment) score to describe organ dysfunction/failure. On behalf of the Working Group on Sepsis-Related Problems of the European Society of Intensive Care Medicine. Intensive Care Med. 1996;22(7):707-10.

92. Lin CY, Kao KC, Tian YC, Jenq CC, Chang MY, Chen YC, et al. Outcome scoring systems for acute respiratory distress syndrome. Shock. 2010;34(4):352-7. doi:10.1097/SHK.0b013e3181d8e61d.

93. Jegal Y, Lee SI, Lee KH, Oh YM, Shim TS, Lim CM, et al. The clinical efficacy of GOCA scoring system in patients with acute respiratory distress syndrome. J Korean Med Sci. 2008;23(3):383-9. doi:10.3346/ jkms.2008.23.3.383

94. Murray JF, Matthay MA, Luce JM, Flick MR. An expanded definition of the adult respiratory distress syndrome. Am Rev Respir Dis. 1988;138(3):720-3. doi:10.1164/ajrccm/138.3.720.

95. Kangelaris KN, Calfee CS, May AK, Zhuo H, Matthay MA, Ware LB. Is there still a role for the lung injury score in the era of the Berlin definition ARDS? Ann Intensive Care. 2014;4(1):4. doi:10.1186/2110-5820-4-4.

96. Calfee CS, Delucchi K, Parsons PE, Thompson BT, Ware LB, Matthay MA, et al. Subphenotypes in acute respiratory distress syndrome: latent class analysis of data from two randomised controlled trials. Lancet Respir Med. 2014;2(8):611-20. doi:10.1016/S2213-2600(14)70097-9.

97. Briel M, Meade M, Mercat A, Brower RG, Talmor D, Walter SD, et al. Higher vs lower positive end-expiratory pressure in patients with acute lung injury and acute respiratory distress syndrome: systematic review and metaanalysis. JAMA. 2010;303(9):865-73. doi:10.1001/jama.2010.218.

\section{Submit your manuscript to a SpringerOpen ${ }^{\odot}$ journal and benefit from:}

- Convenient online submission

- Rigorous peer review

- Immediate publication on acceptance

- Open access: articles freely available online

- High visibility within the field

- Retaining the copyright to your article

Submit your next manuscript at springeropen.com 